\title{
HUKUM MENCEGAH KEHAMILAN PERSPEKTIF IMAM GHAZALI DAN SYEKH ABDULLAH BIN BAAZ
}

\author{
Rifdatus Sholihah \\ MAS Ihyaul Ulum Camgaan Ujungpangkah Gresik. E-mail: \\ rifdatuszzz@gmail.com.

\begin{abstract}
This article discusses the law of preventing pregnancy from the perspective of Imam Ghazali and Sheikh Abdullab bin Baaz. Preventing pregnancy according to Islamic law is permissible. Delaying pregnancy means preventing the pregnancy temporarily, to give a distance to the previous birth. While limiting pregnancy has the meaning of preventing pregnancy forever after having a certain number of children. Pregnancy restrictions like this, are not allowed. Shaykh Abdullah bin Baaz argues that preventing pregnancy, either by 'aql, pills, condoms, and so on is basically haram because it is contrary to maqasid shari'ah, which limits the existence of offspring, but then there are exceptions that make the law permissible, namely because the existence of a dharurat. This is different from Imam Ghazali's assertion, that the Family Planning law which is based on the 'arl law is permissible because there is no text that shows the probibition.
\end{abstract}

Keywords: preventing pregnancy, Imam Ghazali and Sheikh Abdullah bin Baa\%:

Abstrak: Artikel ini membahas tentang hukum mencegah kehamilan perspektif Imam Ghazali dan Syekh Abdullah bin Baaz. Mencegah kehamilan menurut hukum Islam adalah boleh. Menunda kehamilan berarti mencegah kehamilan sementara, untuk memberikan jarak pada kelahiran yang sebelumnya. Sedangkan membatasi kehamilan mempunyai pengertian mencegah kehamilan untuk selamanya seteleh mempunyai jumlah anak dalam jumlah tertentu. Pembatasan kehamilan seperti ini, tidak diperbolehkan. Syekh Abdullah bin Baaz berpendapat, bahwa mencegah kehamilan, baik dengan cara 'ål, pil, kondom, dan lainnya pada dasarnya adalah haram karena bertentangan dengan maqasid shari'ah, yakni membatasi adanya keturunan, tetapi kemudian ada pengecualian yang menjadikan hukumnya boleh, yaitu karena adanya suatu dharurat. Ini berbeda dengan pemikiran Imam Ghazali yang menegaskan, bahwa hukum Keluarga Berencana yang disandarkan kepada hukum 'ąl adalah mubah/boleh karena tidak adanya nas yang menunjukkan keharaman.

Kata Kunci: mencegah kehamilan, Imam Ghazali dan Syekh Abdullah bin Baaz. 


\section{Pendahuluan}

Manusia adalah makhluk ciptaan Allah yang paling sempurna, dengan segala kelebihan yang diberikan oleh-Nya dibanding dengan makhluk lain. Manusia diberi akal pikiran, perasaan, cinta, kasih sayang, serta fisik yang baik, sebagaimana dijelaskan pada QS. AtTin/ 95: 4

"Sesungguhnya Kami telah menciptakan manusia dalam bentuk yang sebaik-baiknya"

Sesuai dengan fitrahnya pula, manusia hidup sebagai makhluk sosial yakni makhluk yang tidak bisa hidup sendiri tanpa kehidupan orang lain. Berbeda dengan hewan yang memang disiapkan Tuhan untuk dapat bertahan hidup sendiri di lingkungannya maupun di lingkungan yang berbeda meskipun tanpa bantuan hewan lain.

Dalam hubungan antara manusia satu dengan yang lain maka yang berpengaruh adalah reaksi yang timbul akibat hubungan yang dilakukan. Menurut Soerjono Soekanto, reaksi itulah yang menyebabkan seseorang bisa bertahan, karena manusia pada dasarnya dilahirkan sudah mempunyai keinginan untuk menjadi satu dengan manusia dan lingkungannya.1

Dalam sejarah peradaban manusia, persekutuan terkecil dalam masyarakat adalah keluarga. Manusia berkembang biak menjadi suatu komunitas masyarakat dalam wujud marga, suku, umat, hingga bangsa. Sebuah keluarga terbentuk berdasarkan hubungan keturunan, hubungan darah, atau melalui proses perkawinan. Secara hukum, sahnya keluarga adalah jika dilangsungkan dalam sebuah ikatan perkawinan. Dalam Undang-Undang disebutkan bahwa "perkawinan adalah ikatan lahir batin antara seorang pria dengan seorang wanita sebagai suami istri dengan tujuan membentuk keluarga (rumah tangga) yang kekal berdasarkan Tuhan Yang Maha Esa".2

Perkawinan dalam Islam tidak hanya dianggap sebagai tempat mencurahkan hasrat biologis manusia belaka, namun merupakan salah satu tanda kekuasaan Allah, sebagaimana firman-Nya QS. arRum: 21:

1 Soerjono Soekanto, Sosiolosi Suatu Pengantar, (Jakarta: Cv Rajawali, 1992), 110.

2 Undang-Undang Perkawinan No. 1 Tahun 1974 Tentang Perkawinan Pasal 1. 
"Dan di antara tanda-tanda kekuasaan-Nya ialab Dia menciptakan untukmu isteri-isteri dari jenismu sendiri, supaya kamu cenderung dan merasa tenteram kepadanya, dan dijadikan-Nya diantaramu rasa kasih dan sayang. Sesungguhnya pada yang demikian itu benar-benar terdapat tanda-tanda bagi kaum yang berfikir".

Salah satu tujuan perkawinan adalah untuk memelihara berlakunya hubungan biologis antara pria dan wanita agar mengembangkan keturunan atau generasi yang baik. Dalam pengembangan keturunan, Islam sendiri tidak menghendaki keturunan yang lemah baik jasmani maupun rohani, sandang, pangan, pendidikan, kesehatan, dan lainnya. Allah Swt. berfirman dalam QS. Surah an-Nisa: 9

"Dan hendaklah takut kepada Allah orang-orang yang seandainya meninggalkan dibelakang mereka anak-anak yang lemah, yang mereka khawatir terhadap (kesejahteraan) mereka. Oleh sebab itu bendaklah mereka bertakwa kepada Allah dan hendaklah mereka mengucapkan perkataan yang benar".

Kata "lemah" pada ayat di atas dipahami sebagai rendahnya kualitas Sumber Daya Manusia. Dari pemahaman itu kemudian diikuti dengan pengajuan sebuah logika, bahwa salah satu pemicu rendahnya kualitas Sumber Daya Manusia tersebut adalah rendahnya tingkat kesejahteraan, dan rendahnya tingkat kesejahteraan salah satu penyebabnya adalah beban hidup yang berat karena banyaknya anak dalam keluarga.

Selain itu dalam hadis Rasulullah Saw. menganjurkan agar setiap laki-laki menikahi perempuan-perempuan yang subur untuk melahirkan keturunan:

"Nikahilah perempuan yang penyayang dan dapat mempunyai anak banyak karena sesungguhnya aku akan berbangga dengan sebab banyaknya kamu di hadapan para

Nabi nanti pada hari kiamat".3

Hadis ini mengandung anjuran untuk memperbanyak keturunan, namun dalam Islam juga memberikan keringanan bagi muslim untuk mengatur keturunannya jika didorong oleh alasan

3 Musnad Anas bin Malik ra, Hadis nomor 13308 (dalam software Jawami’ alKalim) 
yang kuat.4 Tanggung jawab keluarga bukan hanya memberikan kebutuhan lahiriyah saja namun yang penting adalah memberikan kebutuhan pendidikan terhadap anak, baik itu pendidikan formal atau non formal.5 Untuk memberikan kebutuhan pendidikan kepada anak, maka tentunya keluarga perlu melakukan perencanaan serta persiapan agar kehidupannya menjadi lebih baik.

Pertumbuhan penduduk merupakan hal yang sangat berpengaruh terhadap aspek kehidupan yakni kualitas sumber daya manusia. Indonesia yang notabene sebagai negara yang memiliki penduduk terbanyak urutan keempat di dunia dengan jumlah penduduknya 260.580 .739 jiwa (sekitar 260 juta jiwa) atau 35\% dari keseluruhan jumlah penduduk dunia, juga menjadi perhatian bagi Indonesia.6 Jumlah penduduk yang sangat besar dan kurang seimbang dengan daya tampung lingkungan disinyalir akan menjadi suatu permasalahan bagi Indonesia di masa mendatang. Tantangan yang akan dihadapi pun semakin banyak, seperti dalam meningkatkan kesejahteraan rakyat, kesempatan kerja, kemiskinan, peningkatan mutu pendidikan dan kesehatan, serta lainnya. Adanya jumlah penduduk yang tidak disertai dengan ketersediaan lapangan pekerjaan maka pengangguran akan semakin meningkat.

Selain itu, banyaknya pasangan yang menikah di usia muda memilih untuk menunda kehamilan karena alasan yang beragam. Dalam dunia kesehatan (biologis), wanita sudah bisa hamil setelah mendapat menstruasi pertama, artinya seorang wanita sudah dapat mempunyai anak sebelum berusia 20 tahun. Namun, pada usia tersebut sesungguhnya wanita belum siap untuk mempunyai anak. Menurut Badan Kependudukan dan Keluarga Berencana Nasional

4 Syekh Muhammad Yusuf Qardhawi, Halal dan Haram dalam Islam, (Surabaya: Bina Ilmu, 1993), 270.

5 Mardhiyah, "Pengaruh Keikutsertaan Keluarga Berencana terhadap Peningkatan Pendidikan Anak di Kelurahan Pulau Kijang”, (Tesis--Universitas Islam Negeri Suska Riau, 2012), 4.

6 CIA World Factbook Tahun 2017, Ilmupengetahuanumum.com, “diakses pada”, 24 Maret 2019 pukul 20.00 WIB. 
(BKKBN), usia yang ideal untuk hamil adalah 20-30 tahun, dan jika lebih atau kurang dari usia tersebut adalah berisiko.7

Sebagai upaya penanggulangan terhadap masalah yang berkembang, maka pemerintah Indonesia telah mencanangkan program kependudukan untuk meminimalisir pertumbuhan penduduk. Sejak tahun 1973 sebenarnya program tersebut telah dicantumkan dalam GBHN, tentunya dengan mempertimbangkan nilai-nilai agama karena memang mayoritas bangsa Indonesia beragama Islam. 8

Program Keluarga Berencana pertama kali dilaksanakan pada Orde Baru yakni di masa pemerintahan Soeharto. Dengan program ini, masyarakat diharuskan membatasi jumlah kelahiran anak, yaitu setiap keluarga hanya memiliki maksimal dua anak, dan program ini diberlakukan kepada seluruh lapisan masyarakat mulai lapisan bawah hingga atas dalam tatanan masyarakat.9 Keluarga Berencana dapat dianggap sebagai suatu gerakan kultural atau gerakan moral yang mengubah pola pikir, nilai, dan perilaku manusia secara fundamental. Program tersebut dikembangkan untuk dua misi utama yakni menurunkan fertilitas dan meningkatkan kesejahteraan keluarga.10

Keluarga Berencana juga diartikan sebagai suatu usaha atau ikhtiar manusia untuk mengatur kehamilan dalam keluarga yang tujuannya untuk meningkatkan kesejahteraan ibu dan anak dalam mewujudkan keluarga bahagia dan menjadi dasar terwujudnya masyarakat sejahtera sehingga menjamin terkendalinya pertambahan penduduk. Dengan berkembangnya teknologi dan ilmu pengetahuan yang semakin maju, membuat banyak orang sangat

7 Dasri, "Penundaan Kehamilan Dengan Memakai Alat Kontrasepsi Bagi Pengantin Baru Dalam Tinjauan Hukum Islam (Studi Di Kecamatan Selebar Kota Bengkulu)", Jurnal QIY AS Vol. 1, No. 1, (April 2016), 108.

8 M. Ali Hasan, Masail Fiqhiyah al-Haditsah: pada Masalab-masalah Kontemporer Hukum Islam, (Jakarta: PT RajaGrafindo Persada, 1998), 28.

9 Al-Fauzi, "Keluarga Brencana Islam dalam Bingkai Keindonesiaan", Jurnal Lentera: Kajian Keagamaan, Keilmuan dan Teknologi, Volume 3 Nomor 1, (Maret, 2017), 2.

10 Agus Dwiyanto, et al., Penduduk dan Pembangunan, (Yogyakarta: Aditya Media, 1996), 170 . 
mudah untuk mendapatkan sesuatu, seperti mencegah kehamilan yang semakin meningkat.

Kontrasepsi adalah upaya pencegahan konsepsi (pembuahan) atau mencegah terjadinya pertemuan antara sel telur dari wanita dengan sel sperma dari pria saat bersetubuh sehingga tidak terjadi kehamilan. Mereka beranggapan bahwa menggunakan alat kontrasepsi tersebut karena takut tidak terpenuhinya pendidikan, dan kebutuhan pokok lainnya. Namun, masih ada juga yang menggunakan cara 'ąl (Coitus Interruptus) yang telah ada pada zaman Rasulullah. Keluarga Berencana ini termasuk hal yang kontroversional karena beberapa pihak ada yang membolehkan dan ada juga yang melarangnya.

Dalam pembaruan hukum Islam, ada ulama pemikir besar yang terkemuka di dunia Islam abad ke- $5 \mathrm{H}$ yakni Imam Ghazali. Ia terkenal dengan julukan Hujjatul al-Islam (bukti kebenaran Islam). Imam Ghazali merupakan ulama yang produktif dalam menulis, sehingga secara garis besar karangan beliau terbagi dalam empat bidang yakni ilmu kalam, falsafah, batiniyah, dan tasawuf. Diantara buku yang terkenal adalah: Maqasidul Falasifah, Tahafut Falasifah, AlMunqidz Minadhdhalal, dan Ibya' Ulumuddin.11

Terkait Keluarga Bencana dengan mencegah kehamilan maka Imam Ghazali berpandangan dalam kitabnya Ihya' Ulumuddin yakni, bahwa 'ąl (Coitus Interruptus) boleh (tidak dilarang), karena kesukaran yang dialami si ibu disebabkan sering melahirkan. Diantara alasan yang mendorong bolehnya 'ąl adalah:12 (1) untuk menjaga kesehatan si ibu, karena sering melahirkan, (2) untuk menghindari kesulitan hidup karena banyak anak, dan (3) untuk menjaga kecantikan si ibu.

'A₹l pernah dilakukan oleh sebagian sahabat Nabi yang menjimaki budak-budaknya tetapi mereka tidak menginginkannya hamil, dan sebelumnya mereka sudah mendapat izin dari istri mereka.

11 Fitri Nur Hasanah, "Pendidikan Karakter Kajian Pemikiran Imam Al-Ghazali dalam Kitab Ayyuhal Walad”, (Skripsi--Institut Agama Islam Negeri Salatiga, 2017), 3.

12 M. Ali Hasan, Masail Fiqhiyah al-Haditsah ...., 36. 
Berbeda dengan Syekh Abdullah bin Baaz, ia mempunyai pandangan tersendiri terkait hukum Keluarga Berencana dengan mencegah kehamilan. Syekh Abdullah bin Baaz adalah seorang ulama kontemporer yang ahli di bidang sains Hadits, Aqidah, dan Fiqih. Ia pernah menjabat sebagai mufti (penasehat agung) kerajaan Arab Saudi, kepala majelis pendiri Rabithah Alam Islami (Liga Muslim Dunia), rektor Universitas Islam Madinah, anggota dewan tertinggi Hai'ab Kibaril Ulama (semacam MUI di Arab Saudi), dan ketua dari Dewan Riset Ilmu dan Fatwa (al-Lajnah ad-Daimah lil Bubuts al-Ilmiyah wal Ifta').

Menurut Syekh Abdullah bin Baaz, Keluarga Berencana dengan mencegah kehamilan adalah dilarang (haram). Ia berpendapat bahwa membatasi keturunan itu bertentangan dengan kemaslahatan umat Islam karena menjadikan sedikit dan lemahnya kaum muslimin.13 Umat Islam membutuhkan jumlah yang banyak, sehingga dalam beribadah kepada Allah, berjihad di jalan-Nya, melindungi kaum muslimin, dengan izin Allah akan menjaga mereka dari tipu daya musuh-musuh mereka, maka wajib untuk meninggalkan perkara mencegah kehamilan, atau membatasi kelahiran agar tidak menggunakannya kecuali darurat.

Berdasarkan permasalahan yang dirumuskan dalam latar belakang, maka penelitian ini difokuskan mengkaji bagaimana hukum Keluarga Berencana dengan mencegah kehamilan menurut pendapat Imam Ghazali dan Syekh Abdullah bin Baaz dengan penelitian yang berjudul "Hukum Keluarga Berencana dengan Menegah Kehamilan Perspektiff Imam Ghazali dan Syekh Abdullah bin Baaz".

\section{Pengertian Keluarga Berencana}

Keluarga adalah kesatuan sosial terkecil di dalam masyarakat yang diikat oleh sebuah perkawinan yang sah.14 Keluarga Berencana (family planning) menurut Muhammad Syaltut adalah usaha mengatur jumlah kelahiran atau berusaha mencegah kehamilan baik untuk

13 Majmu'u Fatawa wa Maqaalaat Syaikh Bin Baaz

14 Emilia Sari, "Keluarga Berencana Perspektif Ulama Hadis (Family Planning Perspectives on Ulama Hadith)", SALAM; Jurnal Sosial \& Budaya Syar-i, Vol. 6 No. 1 (2019), 57. 
jangka sementara ataupun selamanya sesuai dengan kondisi tertentu. Di beberapa negara Barat, pelaksanaan Keluarga Berencana mencakup dua metode yaitu:

1. Planning parenthood, menitikberatkan pada tanggungjawab kepada kedua orang tua untuk membentuk rumah tangga yang sejahtera walaupun bukan dengan membatasi keturunan.

2. Birth control, lebih menekankan pada menjarangkan kelahiran atau membatasi keturunan.

Menurut Mahjudin, Keluarga Berencana dibagi menjadi dua pengertian, yaitu pengertian umum dan khusus. Pengertian umum ialah suatu usaha yang mengatur banyaknya jumlah kelahiran sedemikian rupa, sehingga bagi ibu maupun bayinya, dan bagi ayah serta keluarganya atau masyarakat yang bersangkutan, tidak akan menimbulkan kerugian sebagai akibat langsung dari kelahiran tersebut. Sedangkan pengertian khusus ialah Keluarga Berencana dalam kehidupan sehari-hari berkisar pada pencegahan konsepsi atau pencegahan terjadinya pembuahan, atau pencegahan pertemuan antara sel sperma dari laki-laki dan sel telur dari perempuan sekitar persetubuhan. 15

Pengertian lain dari Keluarga Berencana adalah suatu program yang dimaksudkan untuk membantu para pasangan suami istri dan perorangan, dalam mencapai tujuan reproduksi mereka, atau mencegah kehamilan yang tidak diinginkan oleh pasangan suami istri dan mengurangi insidens kehamilan berisko tinggi, agar kehidupan keluarga semakin bertambah baik, baik dalam kehidupan ekonomi, kehidupan menjalankan perintah agama, baik kehidupan kesehatan dan perencanaan pendidikan anak-anak.16

Dari beberapa pengertian yang dijelaskan, dapat disimpulkan bahwa Keluarga Berencana adalah pengaturan rencana kelahiran anak dengan melakukan suatu cara atau alat yang dapat mencegah kehamilan. Perencanaan dalam keluarga yakni merencanakan kelahiran dengan merencanakan kehamilan karena memakai atau menggunakan suatu cara atau alat/obat yang disebut kontrasepsi.

15 Suhaedah, "Pengaturan Jarak Kehamilan Menurut al-Qur'an", (SkripsiUniversitas Islam Negeri Alauddin, Makassar, 2013), 17.

16 Mardhiyah, "Pengaruh Keikutsertaan Keluarga Berencana ..., 24. 
Singkatnya, Keluarga Berencana adalah usaha untuk mencegah kehamilan.

Misi program Keluarga Berencana dalam paradigma baru sangat menekankan terkait pentingnya upaya menghormati hak-hak reproduksi sebagai upaya dalam meningkatkan kualitas keluarga. Misi tersebut dijabarkan dalam enam misi kesejahteraan, yaitu:17

1. Memberdayakan masyarakat untuk membangun keluarga kecil berkualitas,

2. Menggalang kemitraan dalam peningkatan kesejahteraan, kemandirian, dan ketahanan keluarga,

3. Meningkatkan kualitas pelayanan KB dan kesehatan reproduksi,

4. Meningkatkan promosi, perlindungan dan upaya mewujudkan hak-hak reproduksi,

5. Meningkatkan upaya pemberdayaan perempuan untuk mewujudkan kesejahteraan dan keadilaan gender melalui program Keluarga Berencana, dan

6. Mempersiapkan sumber daya manusia yang berkualitas sejak pembuahan dalam kandungan sampai dengan lanjut manusia.

\section{Macam-macam Bentuk Mencegah Kehamilan}

Gagasan mengatur besar kecilnya keluarga dalam arti menentukan jumlah anak sebenarnya sudah ada sejak dahulu kala. Biasanya, pengaturan/pembatasan jumlah anak tersebut dengan motif yang berhubungan dengan kesukaran bahan makanan untuk keperluan sehari-hari.

Cara-cara untuk mengurangi jumlah anggota keluarga pada waktu itu seperti:

1. Membunuh anak/bayi. Misalnya dikalangan bangsa Arab pada masa jahiliyah membunuh anak perempuan dengan jalan menguburnya hidup-hidup;

2. Menjual anak/bayi di beberapa negara-negara di Asia;

3. Melakukan pengguguran;

4. Mencegah/menghindari kehamilan dengan

17 Amirul Amalia, "Pengetahuan Tentang KB Menurut Agama Islam Terhadap Pemakaian Alat Kontrasepsi Di BPJS Anik Susanti Amd.Keb. Dusun Jatirejo Desa Topeng Kecamatan Tikung Kabupaten Lamongan", SURYA, Jurnal, Vol.08, No. 01, (April, 2016), 32. 
a. Coitus Interuptus ('az). Cara ini sudah dikenal bangsa Arab pada masa Nabi Muhammad

b. Minum obat/jamu

c. Memperpanjang waktu menyusui

Kemajuan teknologi dan ilmu pengetahuan yang berkembang memunculkan beberapa cara efektif dalam mencegah terjadinya kehamilan yaitu dengan kontrasepsi. Kontrasepsi adalah pencegahan terbuahinya sel telur oleh sel seperma (konsepsi) atau pencegahan menempelnya sel telur yang telah dibuahi ke dinding rahim. Kontrasepsi berfungsi mencegah terjadinya ovulasi, melumpuhkan sperma, dan juga menghalangi pertemuan sel telur dengan sel sperma.18 adalah:

Syarat yang harus dipenuhi oleh suatu metode kontrasepsi

1. Aman/tidak berbahaya,

2. Dapat diandalkan,

3. Sederhana, sedapat-dapatnya tidak usah dikerjakan oleh seorang dokter

4. Dapat diterima oleh orang banyak,

5. Untuk pemakaian jangka lama, dan

6. Murah.19

Beberapa macam alat kontrasepsi yang digunakan dalam pencegahan kehamilan diantaranya:

1. Pil

Yaitu tablet yang berisi bahan progestin dan progesteren yang bekerja dalam tubuh wanita untuk mencegah terjadinya ovulasi dan melakukan perubahan pada hormon endometrium. Pil ini berupa komposisi hormon yang mengandung serat kadar sarang indung telur (ovary). Jenis tablet ini dikonsumsi pada hari ke lima, yakni dimulai sejak hari pertama mendapatkan haid, hinga 20 hari kemudian secara verturut-turut pada setiap bulan.

18 Muhammad Luthfi Afif, "Keluarga Berencana dalam Tafsir al-Azhar", (Skripsi-Universitas Islam Negeri Walisongo, Semarang, 2018), 37.

19 Hartanto, Keluarga Berencana dan Kontrasepsi, (Jakarta: Pustaka Sinar Harapan, 2010), 54 . 
Orang yang pertama kali menggunakan obat (tablet) adalah Gregory Banks pada tahun 1956. Fungsi utamanya adalah mencegah terbentuknya sel telur. Selain itu obat ini juga berfungsi seperti tutup lendir yang menutup leher rahim dari serangan sel sperma laki-laki.

Ada beberapa sisi positif dan sisi negatif menggunakan tablet pencegah kehamilan. Sisi positifnya diantaranya adalah :

a. Mencegah terciptanya indung telur pada tempat telur (ovary);

b. Menguatkan pembuahan (kehamilan) dalam kondisi terjadinya pendarahan pada rahim ketika hamil dan pada saat ada perubahan siklus bulanan/ haid.

Beberapa bahaya menggunakan pil/tablet untuk mencegah kehamilan yaitu:

a. Mengakibatkan gangguan pada anggota perut. Gangguan perut ini dapat membuat muntah, pusing, dan perut terasa berat;

b. Bertambahnya berat badan. Biasanya terjadi di atas enam bulan setelah menggunakan pil tersebut;

c. Gangguan pada hati/ liver;

d. Rasa sakit dan sesak pada bagian payudara;

e. Rasa pusing pada bagian kepala dan perubahan terhadap karakter pribadinya, khususnya terjadi sebelum datang bulan. Selain itu seorang perempuan biasanya akan dikuasai rasa cemburu terhadap suaminya atau tidak ingin berhubungan dengannya;

f. Terjadi gangguan silkus haid. Hal ini bisa terlihat dalam bentuk pendarahan pada masa-masa haid, atau terputusnya haid tersebut sama sekali.

g. Munculnya bintik-bintik kotor yang biasanya terjadi pada bagian wajah, terutama pipi dan hidung;

h. Keluar dan meneteskan air susu dari kedua puting susu, serta dapat mengakibatkan munculnya cairlan lendir dari vagina berwarna putih pekat;

i. Secara psikologis akan menurunkan gairah seksual (libido) bagi perempuan karena perserapan yang dialami oleh seorang wanita ketika mengkonsumsi pil tersebut serta akan 
menghindarkan dari sesuatu yang merangsang saraf-saraf seksualnya.

2. Suntikan

Yaitu menginjeksi cairan ke dalam tubuh wanita yang dikenal dengan Caoro Devo Provera, Net Den, dan Noristerat. Cara kerja suntikan ini adalah menghalangi terjadinya ovulasi, menitipkan endometrium sehingga vidasi tidak mungkin terjadi dan memekatkan lendir sevik sehingga menghambat perjalanan sperma melalui canalis servikalis.

Kontra indikasi tidak disuntikkan kepada wanita yang sedang hamil, mengidap tumor ganas, yang mengidap sakit jantung, paru-paru, liver, hupertensi, dan diabetes. Ada beberapa bahaya menggunakan suntikan ini untuk mencegah kehamilan seperti terganggunya haid, kepala pusing, mual, timbulnya jerawat, rambut rontok, naiknya berat badan, hingga alergi.

3. Susuk KB

Yaitu berupa leve morgestrel tersendiri dari enam kapsul yang diinseresikan kebawah kulit lengan bagian dalam kira-kira 6 sampai $10 \mathrm{~cm}$ dari lipat siku-siku. Susuk $\mathrm{KB}$ ini bertahan sampai waktu 5 tahun. Cara kerja dan efek samping susuk KB ini sama dengan suntikan.

4. Alat Kontrasepsi Dalam Rahim (AKDR)

Yaitu alat dalam KB yang terdiri dari lippessloap (spiral), multiload, dan Co Copper $-\mathrm{T}$ yang terbuat dari plastik halus dan dililit dengan tembaga tipis. Cara kerjanya adalah membuat lemahnya daya sperma untuk membuahi sel telur wanita karena penyempitan akar regangan spiral dan pengaruh tembaga yang melilit pada plastik itu. Efektivitas dari AKDR sendiri mencapai $98 \%$ dan bisa bertahan lama.

Alat ini berupa bulatan kecil yang memiliki corak dan tipe yang beragam. Ada yang terbuat dari plastik, paku, atau peniti yang terbuat dari platinum atau lainnya. Alat ini didorong ke dalam rahim dan harus dengan bantuan dokter atau bidan. Alat ini akan menetap selamanya dalam rahim untuk mencegah terjadinya pembuahan pada dinding rahim. adalah:

Alat spiral ini ada bahayanya jika digunakan diantaranya 
a. Pendarahan yang terjadi secara terputus-putus atau terusmenerus tapi tidak berkepanjangan;

b. Timbul rasa sakit seperti serangan yang menyakitkan, seakan-akan terjadi penyusutan pada rahim seperti rasa sakit ketika sedang haid;

c. Peradangan yang terjadi setelah pemasangan spiral karena biasanya pada pemasangan spiral dapat mengaktikan kuman atau bakteri yang ada pada rahim;

d. Sensitivitas khusus terhadap IUD berbahan tembaga atau kuningan;

e. Kehamilan di luar rahim (kehamilan ektopik).

5. Sterilisasi

Merupakan kemandulan yang disengaja. Sterilisasi adalah metode mencegah kehamilan yang menyebabkan wanita tidak dapat hamil lagi. Tujuan sterilisasi diantaranya yaitu:

a. Indikasi medis, yang biasa dilakukan oleh wanita yang mengidap penyakit yang dianggap berbahaya bagi dirinya, seperti sakit jantung, ginjal, dan hipertensi

b. Sosial ekonomi,yaitu suami istri tidak bisa memenuhi kewajiban untuk mengurus anak karena terlalu miskin

c. Karena permintaan sendiri

Beberapa cara yang dilakukan pada proses sterilisasi wanita yakni:

a. Radiasi, wanita tidak bisa lagi menghasilan hormon-hormon sehingga menjadi tidak produktif bahkan bisa menopouse

b. Operatif, biasanya dilakukan dengan teknik ovarektomi (mengangkat ovarium), tubektomi (mengangkat seluruh tuba agar tidak bisa hamil karena saluran sudah bocor), dan ligasi tuba (mengikat tuba sehingga tidak dapat dilewati oleh ovum).

c. Cara penyumbatan tuba, yaitu menggunakan zat-zat kimia untuk menyumbat lubang tuba dengan teknik suntikan.

6. Kondom

Yaitu selubung atau sarung karet yang terbuat dari berbagai bahan seperti karet (lateks), plastik (vinil), atau bahan alami yang dipasang pada penis untuk menampung sperma 
ketika seorang peria mencapai ejakulasi. Kondom terbuat dari karet sintesis yang tipis dan berbentuk silinder.

7. Metode kalender atau pantang berkala

Metode ini termasuk metode kontrasepsi sederhana yang dilakukan oleh pasangan suami istri dengan tidak melakukan hubungan seksual pada masa subur atau ovulasi. Metode ini berdasarkan dari siklus haid wanita.20

\section{Profil Imam Ghazali}

Imam Ghazali adalah seorang teolog, filsuf, dan sufi terbesar Islam yang mendalami fikih, kalam dan filsafat. Beliau merupakan figur yang tidak asing dalam dunia pemikiran Islam, karena banyak orang menemukan namanya dalam berbagai literatur, baik klasik maupun modern.21 Sebagai pembela kebenaran Islam terbesar, menjadikan Imam Ghazali mendapat gelar bujjatul al-Islam (bukti kebenaran Islam).

Nama lengkap Imam Ghazali adalah Abu Hamid Muhammad bin Muhammad at-Tusi al-Ghazali. Beliau lahir pada tahun 450 H/1058 M di sebuah desa bernama Gazalah, kota Tus kawasan Khurasan Iran yang ketika itu termasuk salah satu pusat ilmu pengetahuan di dunia Islam.22 Ayahnya, Muhammad bekerja sebagai pemintal bulu kambing dan pedagang kain wol. Oleh karena itu beliau dikenal dengan sebutan al-Ghazzali (dengan huruf $z a$ bertasydid) yang berarti "pemintal benang", karena memang keluarganya bekerja sebagai pemintal benang. Ada juga di literatur lain yang berpendapat bahwa al Ghazali (dengan huruf za tanpa tasydid) merujuk kepada kota Ghazalah, tempat Imam Ghazali berasal.23

Imam Ghazali lahir dari keluarga yang taat beragama dan hidup sederhana. Selain kesibukan ayahnya yang bekerja, ayah Imam Ghazali juga selalu menghadiri majelis-majelis pengajian yang

20 Mahmudin Bunyamin, Agus Hermanto, Fiqh Kesehatan....., 48-55.

21 M. Sholihin, Epistemologi Ilmu dalam Pandangan Imam Al-Ghazali, Jakarta: Pustaka Setia, 2001), 9.

22 Abdul Aziz Dahlan, Ensiklopedi Hukum Islam Jilid 2, (Jakarta: PT Intermasa, 2006), 203.

23 Anindya Rizka Ayunda, "al-Ghazali: Antara Filsafat dan Tasawuf”, UIN Sunan Gunung Djati, Bandung, 1. 
diselenggarakan ulama. Imam Ghazali punya seorang saudara lakilaki bernama Abu al-Futuh Ahmad bin Muhammad bin Muhammad bin Ahmad at-Tusi al-Gazali, yang dikenal dengan julukan Majduddin. Keduanya, Imam Ghazali dan saudaranya menjadi ulama besar, namun bedanya Majduddin lebih cenderung kepada kegiatan dakwah sedangkan Imam Ghazali cenderung menjadi penulis dan pemikir.

Perjalanan keilmuwan Imam Ghazali dimulai dengan belajar al-Quran pada ayahnya sendiri. Namun sepeninggal sang ayah, yakni ketika beliau berusia 6 tahun, beliau dan saudaranya di didik oleh seorang sufi yang mendapat wasiat dari ayahnya untuk mengasuh mereka yakni Ahmad bin Muhammad ar-Razikani. Kepadanya, Imam Ghazali belajar al-Quran, hadits, ilmu fikih, tentang riwayat hidup para wali, dan kehidupan spiritual. Selain itu, beliau juga menghafal syair-syair mahabbah (tentang cinta dan orang yang mabuk cinta). 24

Imam Ghazali kemudian dimasukkan ke sebuah sekolah yang menyediakan beasiswa bagi para muridnya, karena bekal yang telah dititipkan ayahnya pada Muhammad Al-Rizkani habis. Gurunya adalah Yusuf al-Nassi, juga merupakan seorang sufi. Di madrasah ini Imam Ghazali mulai belajar fikih. Setelah tamat, Imam Ghazali melanjutkan pelajarannya ke kota Jurjan, yakni sebuah kota di Persia yang terletak antara kota Tabristan dan Nisabur. Di sana, beliau memperluas wawasannya tentang fikih dengan berguru kepada ahli fakih bernama Imam Abu Nasr al-Ismail (Abu al-Qasim Ismail bin Mus'idah al-Ismail).

Beberapa tahun kemudian, Imam Ghazali pergi ke Nisabur. Disana beliau masuk di Madrasah Nizamiyah yang dipimpin oleh ulama besar bernama Abu Al-Ma'ali al-Juwaini dan bergelar Imam al-Haramain, seorang teolog aliran Asy'ariyah. Di Madrasah Nizamiyah Imam Ghazali memperoleh ilmu ushul fikih, ilmu fiqh, mantiq, ilmu kalam serta tasawuf. Karena dinilai berbakat dan berpotensi, al-Juwaini memujinya bagaikan lautan tak bertepi sehingga beliau diangkat menjadi asisten al-Juwaini. Beliau juga

24 Achmad Faizur Rosyad, Mengenal Alam Suci Menapak Jejak Al-Ghazali, (Yogyakarta: KUTUB, 2004), https://ririelbangunperadaban.wordpress.com, “diakses pada" 25 Juni 2019. 
mempelajari tasawuf kepada gurunya yang sufi seperti Imam Abu Ali al-Fadhl bin Muhammad bin Ali al-Farmazi at-Tusi, belajar hadits kepada ulama seperti Abu Sahal Muhammad bin Ahmad alHafsi al-Mawarzi, Abu al-Fath, Nasr bin Ali bin Ahmad al-Hakimi at-Tusi, Abu Muhammad Abdullah bin Muhammad as-Sujja'i azZauzani, al-Hafidz Abu al-Fityan Umar bin Abi al-Hasan ar-Ru'asi ad-Dahistani, dan Nasr bin Ibrahim al-Maqdisi.25

Setelah Imam Haramain wafat, Imam Ghazali meninggalkan Nisabur menuju Muaskar26 untuk memenuhi undangan Perdana Menteri Nizam al Mulk, pendiri Madrasah Nizamiyah. Disana beliau disambut dengan penuh kehormatan sebagai seorang ulama besar dan karena kepandaiannya, Imam Ghazali dilantik sebagai guru besar (profesor) pada Madrasah Nizamiyah yang berada di Kota Baghdad, berjenjang mulai dari dasar hingga perguruan tinggi. Di Madrasah ini Imam Al-Ghazali bertugas selama 4 tahun atau 5 tahun (1090- 1095H).

Kehidupan Imam Ghazali pernah mengalami keraguan dan kegelisahan yang muncul setelah dirinya mempelajari ilmu kalam (teologi) kepada al-Juwaini. Beliau tidak percaya pada pengetahuan yang diperolehnya melalui panca indera karena panca indera sering salah atau dusta. Akhirnya beliau mendapatkan pengetahuan tasawufnya melalui kalbu dan menemukan pengetahuan kebenaran.

Empat tahun berselang tepatnya tahun 1905, Imam Ghazali meninggalkan Baghdad untuk menunaikan ibadah haji. Kemudian beliau ke Damaskus dan dan iktikaf di Masjid Umawi dan hidup sebagai seseorang zahid yang mendalami suasana batin, meninggalkan kemewahan dan menyucikan diri dari dosa. Disinilah beliau menulis kitabnya yang berjudul Ibya' Ulumuddin, sebuah kitab yang merupakan paduan antara fikih dan tasawuf.

Setelah itu beliau kembali lagi ke Baghdad untuk meneruskan kegiatan mengajarnya pada tahun $499 \mathrm{H}$. Akan tetapi pekerjaannya ini hanya berlangsung selama dua tahun dan akhirnya kembali ke kota Thus lagi. Imam Ghazali kemudian mendirikan sebuah sekolah untuk para fuqaha dan sebuah biara (khangak) untuk para

25 Abdul Aziz Dahlan, Ensiklopedi Hukum Islam Jilid 6...., 404.

26 Pada waktu itu adalah tempat permukiman perdana menteri, pembesarpembesar kerajaan, dan para ulama terkemuka. 
mutasamnifin yang diasuhnya sampai beliau wafat pada tahun 505 $\mathrm{H} / 1111 \mathrm{M}$.

Imam Ghazali menjalani kehidupan pada masa tuanya sebagai seorang sufi. Beliau berkeyakinan bahwa tasawuf adalah satusatunya jalan untuk mencapai kebenaran hakiki dimana seseorang bisa berada dekat dengan Tuhan bahkan dengan kalbunya dapat melihat Tuhan.

\section{Pandangan Imam Ghazali tentang Hukum Mencegah Kehamilan}

Imam Ghazali menjelaskan dalam Ihya' Ulumuddin bahwa ada empat klasifikasi terkait Keluarga Berencana dengan mengambil hukum 'ą̧ untuk mencegah kehamilan:

1. Boleh secara mutlak;

2. Dilarang/haram secara mutlak;

3. Boleh dengan syarat izin istri dan setuju, jika tidak mendapat izin maka tidak tidak boleh, dan yang menjadi pokok pengharaman adalah haramnya menyakiti istri;

4. Boleh jika dilakukan dengan budak yang dimiliki, tetapi tidak dengan istri;

Dalam penjelasan selanjutnya Imam Ghazali mengatakan, "pencegahan kehamilan adalah diizinkan/boleh" karena beberapa sebab, salah satunya termasuk kesukaran yang dialami oleh ibu sebab seringnya melahirkan.27

Ada beberapa motif yang juga mendukung alasan bolehnya 'ąl antara lain:

1. Memelihara kecantikan dan kesehatan wanita;

2. Melindungi wanita dari situasi yang menyusahkan (dicerai);

3. Menghindarkan diri dari kepayahan fisik sebagai konsekuensi jika mempunyai terlalu banyak anak.

Syekh Wahbah Zuhailiy menjelaskan:

"Hanya ulama dari kalangan madzhab Syafi'i, Hanbali, dan sejumlah sahabat menyatakan kemakruhan 'ąl karena Rasulullah Saw. dalam riwayat Muslim dari Siti Aisyah menyebut 'azl sebagai pembunuhan samar-samar. Larangan dalam riwayat ini dipahami sebagai makruh tanzih yang

27 Al-Fauzi, "Keluarga Brencana Islam...., 12. 
sebaiknya tidak dilakukan. Tetapi Imam Al-Ghazali membolehkan 'azl karena sejumlah sebab, salah satunya kemunculan banyak 'problem' yang dipicu oleh kebanyakan anak. Atas dasar pandangan Al-Ghazali ini, penggunaan alat kekinian perencanaan jumlah anak seperti pil $\mathrm{KB}$ atau media KB lainnya untuk jangka waktu tertentu yang tidak berdampak pada penutupan sama sekali kemungkinan kehamilan atau tidak merusak benih janin normal, diperbolehkan,"28

Jadi menurut Imam Ghazali hukum Keluarga Berencana dengan menyandarkan pada hukum ' $a$ l l untuk mencegah kehamilan itu boleh dan tidak makruh karena tidak ada nash yang mengharamkan dan memakruhkannya. Pembolehan 'ą̧ ini juga berlaku untuk bolehnya penggunaan alat kontrasepsi untuk mencegah kehamilan. Imam Ghazali menambahkan 'ąl dilakukan karena memang ada problem/masalah jika terjadi kehamilan itu, maka sebaiknya kehamilan itu direncanakan.

Imam Ghazali mengambil dalil dalam riwayat Jabir dimana sebagian sahabat Nabi pernah melakukan 'azl sedangkan Nabi tidak melarangnya.

"Dari sahabat Jabir berkata: kami melakukan 'ąl pada masa

Nabi sedangkan ketia itu al-Quran masih turun, kemudian berita peristiwa ini sampai kepada Rasulullah dan beliau tidak melarang kami”.29

\section{Profil Syekh Abdullah bin Baaz}

Syekh Abdulah bin Baaz adalah seorang ulama kontemporer yang ahli dibidang sains Hadits, Aqidah, dan Fiqih. Syekh Abdulah bin Baaz lahir di Riyadh Arab Saudi tahun 1909 M/1330 H.

Nama aslinya adalah Abdul Aziz bin Abdullah bin Abdurrahman bin Muhammad bin Abdullah Alu Baz. Alu Baz (keluarga Baz) adalah sebuah keluarga yang berasal dari kota

28Syekh Wahbah Az-Zuhayli, Al-Fiqhul Islami wa Adillatubu, cetakan ke-2, 1985 M/1305, (Beirut: Darul Fikr, juz 3, 554-555).

29 Imam Muslim, Sabih Muslim, Hadits nomor 2618 (dalam software Jawami’ alKalim) 
Madinah. Namun, seiring dengan berjalannya waktu, sebagian mereka pindah ke Dir'iyyah, Huthah Bani Tamim dan Riyadh. AsySyaikh Abdul Aziz bin Baz dan keluarga besar beliau termasuk dari mereka yang berdomisili di kota Riyadh. Di Kerajaan Saudi Arabia, Alu Baz (keluarga Baz) termasuk keluarga yang mempunyai andil besar di bidang ilmu agama, perdagangan, dan pertanian.30

Saat usianya masih sangat kecil, Syekh Abdulah bin Baazmampu menghafal Al-Qur'an, beliau menyetorkan hafalannya kepada Syaikh Abdullah bin Furaij. Syekh Abdulah bin Baaz mempelajari ilmu-ilmu syariat dan bahasa Arab melalui bimbingan ulama-ulama disekitar kota Riyadh. Ketika mulai belajar agama saat masih kecil Syekh Abdulah bin Baaz bisa melihat dengan baik dan normal, namun diusianya sekitar 16 tahun mata beliau terkena sebuah infeksi yang berangsur membuatnya sakit dan rabun. Penglihatannya perlahan memburuk hingga akhirnya mengalami kebutaan total di usia 20 tahun.

Syekh Abdulah bin Baaz pernah menjabat sebagai mufti (penasehat agung) kerajaan Saudi Arabia, kepala majelis pendiri Rabithah Alam Islami (Liga Muslim Dunia), rektor Universitas Islam Madinah, anggota dewan tertinggi Hai'ah Kibaril Ulama (semacam MUI di Arab Saudi), dan ketua dari Dewan Riset Ilmu dan Fatwa (al-Lajnah ad-Daimah lil Buhuts al-Ilmiyah wal Ifta'). Beliau meninggal dunia pada tahun $1999 \mathrm{M} / 1420 \mathrm{H}$ dan disemayamkan di pemakaman Al-Adl, Makkah.

Aqidah dan manhaj dakwahnya bisa dilihat dari tulisan maupun karya-karyanya. Misalnya dalam buku "al-Aqidah ashShahihah" yang menerangkan aqidah Ahlussunnah wal Jamaah, menegakkan Tauhid dan menjauhkan sekaligus memerangi kesyirikan. Syekh Abdulah bin Baaz benar-benar menyandarkan tafsir Al-Qur'an dan syarah hadits-hadits yang dibawakan dalam kitab-kitabnya pada pemahaman Salafus Shalih (pemahaman para Shahabat) serta ulama-ulama ahlussunnah yang mengikuti mereka. Pembelaannya terhadap aqidah tauhid dan sunnah yang murni pun tertuang dalam banyak karyanya, salah satunya adalah "at-Tahdzir 'alal Bida"'. Beliau telah membangun halaqah (majlis) pengajaran di

30https:/ / asysyariah.com/biografi-as-y-syaikh-abdul-aziz-bin-bazrahimahullah/“diakses pada” 25 Juni 2019 
Jami' al-Kabir (Masjid Jami' Besar) di Riyadh sejak berpindah ke sana.

\section{Pandangan Syekh Abdullah bin Baaz tentang Keluarga Berencana}

Syekh bin Baaz berpendapat tentang hukum KB dengan mengkonsumsi pil atau dengan alat kontrasepsi lainnya termasuk dengan cara sederhana seperti 'azl untuk mencegah kehamilan hukumnya adalah haram, apalagi jika tujuannya membatasi keturunan secara permanen. Menurutnya, hal itu bertentangan dengan maqashid syariah yang menganjurkan agar umat Islam memperbanyak keturunan, sehingga upaya-upaya yang dilakukan untuk menyedikitkan keturunan sangat tidak sejalan dengan syari'at bertanasul.31

Fatwa ini mendasarkan pada hadis shahih yang diriwayatkan oleh Abu Dawud, Ibnu Hibban dan Al-Hakim:

Hadis ini menganjurkan bahwa umat manusia harus memperbanyak keturunan, maka wajib untuk meninggalkan perkara mencegah kehamilan tersebut. Namun ada pengecualian terkait mencegah kehamilan bisa menjadi boleh, yakni jika dalam keadaan darurat, kondisi itu seperti:

1. Istri tertimpa penyakit di dalam rahimnya atau anggota badan yang lain, sehingga berbahaya jika hamil, maka tidak mengapa (mencegah kehamilan) untuk keperluan ini.

2. Jika sudah memiliki anak banyak, sedangkan istri keberatan jika hamil lagi, maka boleh mencegah kehamilan misalnya dengan mengkonsumsi pil pencegah kehamilan dalam waktu tertentu, seperti setahun atau dua tahun dalam masa menyusui, sehingga si istri merasa ringan untuk kembali hamil, sehingga ia bisa mendidik dengan selayaknya.32

Dalam kitab fatwanya, Syekh Abdullah bin Baaz menjelaskan bahwa tidak apa-apa/boleh memakai alat kontrasepsi untuk mengatur jarak kelahiran agar menghindari kemudharatan. Akan tetapi, hal itu sebaiknya dilakukan pada masa menyusui (tahun

31 Tanasul adalah berketurunan atau memperbanyak keturunan

32 Fatwa Lajnah Daimah 2, Dewan Riset Ilmu dan Fatwa (al-Lajnah ad-Daimah lil Bubuts al-Ilmiyab wal Ifta'), sumber: https://archive.org/details/KumpulanFATWA, Diakses 26 juni 201921.00 
pertama dan kedua) sehingga tidak kemudharatan untuk kehamilan berikutnya dan akhirnya juga tidak menimbulkan efek buruk terhadap pendidikan anak serta kesehatan si ibu. 33

\section{Persamaan Pendapat Tentang Mencegah Kehamilan Antara Imam Ghazali Dan Syekh Abdullah Bin Baaz}

Imam Ghazali dan Syekh Abdullah bin Baaz memiliki pendapat yang sama bahwa melakukan program Keluarga Berencana itu boleh karena adanya beberapa problem atau masalah yang terjadi. Praktik Keluarga Berencana yang dimaksud tentunya berbagai macam cara, termasuk ' $a$ l, menggunakan pil, dan lainnya. Namun jika memang dari awal sudah berniat ingin mencegah kehamilan tanpa adanya suatu alasan yang jelas maka tidak boleh dilakukan.

Dari pendapat Imam Ghazali dan Syekh Abdullah bin Baaz mengenai alasan yang boleh dilakukan untuk melakukan pencegahan kehamilan jika disimpulkan diantaranya adalah:

1. Menjaga kesehatan dan kecantikan ibu;

2. Untuk memberikan kesempatan bagi ibu agar beristirahat antara dua kehamilan;

3. Jika salah satu atau kedua suami istri itu memiliki penyakit yang berbahaya;

4. Jika keuangan suami istri tidak mencukupi untuk membiayai banyak anak.

Menurut Imam Ghazali tidak adanya nash yang jelas yang diqiyaskan atas keharaman 'ąl, tetapi ashl yang digunakan, yakni menyamakan hukum 'azl dengan meninggalkan jimak setelah nikah atau tidak melakukan inzal/ persetubuhan. Maka ini bermakna larangan. Selain itu mengingat karena proses lahirnya anak ada beberapa tahapan yang dilalui mulai dari menikah, melakukan jimak, dan berhenti untuk melakukan inzal (menumpahkan sperma di dalam rahim). Ketiga proses lahirnya anak tersebut saling berkaitan, oleh karena itu jika satu saja dilarang maka sama dengan melarang yang lainnya juga.

33 Abdul Aziz bin Abdullah bin Abdurrahman bin Baaz, Majmu'u Fatawa wa Maqaalaat Syaikh Bin Baaz, Jilid 21, (Riyadh:Dar al-Qasim, 1425 M/2004 M), 191. 
Sebagaimana yang kita ketahui bahwa Islam sangat suka terhadap banyaknya keturunan dan memberkati setiap anak, baik laki-laki ataupun perempuan. Namun di balik itu Islam juga memberi kemudahan kepada setiap muslim untuk mengatur keturunannya itu apabila didorong oleh alasan kuat.

Dalam kaidah fikih pun sudah dijelaskan bahwa segala sesuatu yang mudharat atau sulit itu bisa dihilangkan ( الضرر يزال). Seperti yang dikatakan oleh Izzudin Ibn 'Abd al-Salam bahwa tujuan syariah adalah untuk mencapai kemaslahatan dan menolak mafsadah/ kemungkaran atau setidaknya meringankannya.34 Oleh karena itu bisa kita lihat di Indonesia sendiri melegalkan adanya KB. Pemerintahpun melakukan upaya untuk mencapai tujuan kemasalahatan rakyat untuk mengatasi banyaknya penduduk yang tidak seimbang tersebut, sesuai dengan kaidah:

"Kebijaksanaan imam (pemerintahan) terhadap rakyatnya

bisa dihubungkan dengan (tindakan) kemaslahatan."

Maksud kaidah ini bahwa setiap kebijakan yang maslahat dan manfaat bagi rakyat maka itu yang harus direncanakan, dilaksanakan, diorganisasikan dan dievaluasi kemajuannya. Sebaliknya, kebijakan yang mendatangkan mafsadah dan memudharatkan rakyat, maka itu yang harus dijauhi.35Jadi masalah KB bukan masalah yang mutlak mengenai boleh tidaknya, tetapi bergantung hukum bolehnya kepada keadaan dan illat yang melingkupinya.

\section{Perbedaan Pendapat Tentang Hukum Mencegah Kehamilan antara Imam Ghazali dan Syekh Abdullah Bin Baaz}

Menurut Syekh Abdullah bin Baaz mengenai pelaksanaan Keluarga Berencana baik itu dengan cara sederhana seperti 'azl maupun dengan cara yang sudah ada seperti menggunakan pil, kondom, dan lainnya pada dasarnya adalah haram, tetapi kemudian ada pengecualian yang menjadikan hukum kebolehan dengan adanya suatu dharurat. Ini berbeda dengan pendapat Imam Ghazali yang berpendapat bahwa hukum Keluarga Berencana yang disandarkan dengan hukum 'ąl adalah mubah/boleh.

34 A. Djazuli, Kaidah-Kaidab Fikih: Kaidah-Kaidah Hukum Islam dalam Menyelesaikan Masalah-Masalah yang Praktis, (Jakarta: Prenadamedia Group, 2006), 67.

35 Ibid, 148. 
Pengharaman atas hukum mencegah kehamilan menurut Syekh bin Baaz bahwa itu termasuk menjadikan sedikitnya jumlah umat Islam dan menjadikan lemahnya kaum muslim. Jika dianalisis maka pendapat tersebut harus dilihat dulu dengan konteksnya karena pada zaman Nabi umat Islam sedikit secara kuantitas. Padahal untuk meneguhkan eksistensi Islam saat itu kuantitas sangat dibutuhkan dan menjadi sesuatu yang mutlak. Maka Nabi memberi perintah agar umat Islam mempunyai banyak keturunan.

Menggunakan alat-alat kontrasepsi atau sarana lain yang mengakibatkan alat-alat reproduksi tidak berfungsi dan mengakibatkan tidak dapat menghasilkan keturunan, baik pada pria maupun wanita, dengan persetujuan ataupun tidak, dengan motivasi agama atau lainnya, maka hukumnya haram. Contoh yang diharamkan adalah vasektomi (pemutusan saluran sperma) dan tubektomi (pemutusan saluran telur).

Allah Swt. berfirman:

Yang dilaknati Allah dan syaitan itu mengatakan: "Saya benar-benar akan mengambil dari hamba-hamba Engkau bahagian yang sudah ditentukan (untuk saya), dan aku benar-benar akan menyesatkan mereka, dan akan membangkitkan angan-angan kosong pada mereka dan menyurub mereka (memotong telinga-telinga binatang ternak), lalu mereka benar-benar memotongnya, dan akan aku surub mereka (mengubah ciptaan Allab), lalu benar-benar mereka meubabnya". Barangsiapa yang menjadikan syaitan menjadi pelindung selain Allah, Maka sesunggubnya ia menderita kerugian yang nyata. Pada tiap-tiap manusia ada persediaan untuk baik dan ada persediaan untuk.jahat, syaitan akan mempergunakan persediaan untuk jahat untuk. mencelakakan manusia. Menurut kepercayaan Arab jabiliyah, binatang-binatang yang akan dipersembabkan kepada patung-patung berbala, haruslab dipotong telingany a lebih dahulu, dan binatang yang seperti ini tidak boleh dikendarai dan tidak dipergunakan lagi, serta harus dilepaskan saja.36

Merubah ciptaan Allah yang dilarang di antaranya merubah sesuatu dari anggota badannya atau mematikan fungsinya dari fitrah dan penciptaan yang asli. Syari'ah Islam tidak melarang seseorang 
untuk melakukan KB jika dilakukan berdasarkan motivasi-motivasi pribadi dengan syarat-syarat yang sesuai syar'i, seperti: daf'ul haraj (menolak kesempitan), ad-dharar yuzaal (bahaya harus di hilangkan). Sebagaimana ciri khas ajaran Islam dalam al-Qur'an:

Dan Dia sekali-kali tidak menjadikan untuk kamu dalam agama suatu kesempitan".37

\section{Penutup}

Berdasarkan hasil analisis penulis tentang hukum Keluarga Berencana dengan mencegah kehamilan perspektif Imam Ghazali dan Syekh Abdullah bin Baaz dapat diambil kesimpulan sebagai berikut: Keluarga Berencana dengan mencegah kehamilan menurut hukum Islam adalah boleh, artinya bahwa menunda kehamilan yang berarti mencegah kehamilan sementara untuk memberikan jarak pada kelahiran yang sebelumnya Sedangkan membatasi kehamilan mempunyai pengertian mencegah kehamilan untuk selamanya seteleh mempunyai jumlah anak dalam jumlah tertentu maka tidak diperbolehkan.

Menurut Imam Ghazali hukum Keluarga Berencana dengan menyandarkan pada hukum 'azl untuk mencegah kehamilan itu boleh dan tidak makruh karena tidak ada nash yang mengharamkan dan memakruhkannya. Pembolehan 'azl ini juga berlaku untuk bolehnya penggunaan alat kontrasepsi untuk mencegah kehamilan. Syekh bin Baaz berpendapat bahwa hukum KB dengan mengkonsumsi pil atau dengan alat kontrasepsi lainnya termasuk dengan cara sederhana seperti 'arl untuk mencegah kehamilan hukumnya adalah haram, apalagi jika tujuannya membatasi keturunan secara permanen. Menurutnya, hal itu bertentangan dengan maqashid syariah.

Imam Ghazali dan Syekh Abdullah bin Baaz memiliki kesamaan dan perbedaan tentang hukum Keluarga Berencana. Persamaan tersebut adalah bahwa melakukan program Keluarga Berencana itu boleh karena adanya beberapa problem atau masalah yang terjadi. Praktik Keluarga Berencana yang dimaksud tentunya berbagai macam cara, termasuk ' $a$ l, menggunakan pil, dan lainnya. Untuk perbedaan sudut pandang, Syekh Abdullah bin Baaz

37 Q.S. al-Hajj: 78 
berpendapat mengenai pelaksanaan Keluarga Berencana baik itu dengan cara sederhana seperti 'azl maupun dengan cara yang sudah ada seperti menggunakan pil, kondom, dan lainnya pada dasarnya adalah haram dengan alasan karena bertentangan dengan maqashid syari'ah yakni membatasi adanya keturunan, tetapi kemudian ada pengecualian yang menjadikan hukum kebolehan dengan adanya suatu dharurat. Ini berbeda dengan pendapat Imam Ghazali yang berpendapat bahwa hukum Keluarga Berencana yang disandarkan dengan hukum ' $a$ l l adalah mubah/boleh karena tidak adanya nash yang menunjukkan keharaman.

\section{Daftar Pustaka}

A. Djazuli, Kaidah-Kaidah Fikih: Kaidah-Kaidah Hukum Islam dalam Menyelesaikan Masalab-Masalab yang Praktis, Jakarta: Prenadamedia Group, 2006.

Abdul Aziz bin Abdullah bin Abdurrahman bin Baaz, Majmu'u Fatawa wa Maqalat Syaikh Bin Baaz, Jilid 21, Riyadh: Dar alQasim, $1425 \mathrm{M} / 2004 \mathrm{M}$.

Abdul Aziz Dahlan, Ensiklopedi Hukum Islam Jilid 2, Jakarta: PT Intermasa, 2006.

Achmad Faizur Rosyad, Mengenal Alam Suci Menapak Jejak AlGhazali, Yogyakarta: KUTUB, 2004, https://ririelbangunperadaban.wordpress.com, “diakses pada" 25 Juni 2019.

Agus Dwiyanto, et al., Penduduk dan Pembangunan, Yogyakarta: Aditya Media, 1996.

Al-Fauzi, "Keluarga Brencana Islam dalam Bingkai Keindonesiaan", Jurnal Lentera: Kajian Keagamaan, Keilmuan dan Teknologi, Volume 3 Nomor 1, (Maret, 2017).

Amirul Amalia, "Pengetahuan Tentang KB Menurut Agama Islam Terhadap Pemakaian Alat Kontrasepsi Di BPJS Anik Susanti Amd.Keb. Dusun Jatirejo Desa Topeng Kecamatan Tikung Kabupaten Lamongan", SURYA, Jurnal, Vol.08, No. 01, (April, 2016).

Anindya Rizka Ayunda, "al-Ghazali: Antara Filsafat dan Tasawuf", UIN Sunan Gunung Djati, Bandung.

CIA World Factbook Tahun 2017, Ilmupengetahuanumum.com, “diakses pada”, 24 Maret 2019 pukul 20.00 WIB. 
Dasri, "Penundaan Kehamilan Dengan Memakai Alat Kontrasepsi Bagi Pengantin Baru Dalam Tinjauan Hukum Islam (Studi Di Kecamatan Selebar Kota Bengkulu)", Jurnal QIYAS Vol. 1, No. 1, (April 2016).

Emilia Sari, "Keluarga Berencana Perspektif Ulama Hadis (Family Planning Perspectives on Ulama Hadith)", SALAM; Jurnal Sosial \& Budaya Syar-i, Vol. 6 No. 1 (2019).

Fatwa Lajnah Daimah 2, Dewan Riset Ilmu dan Fatwa (al-Lajnah ad-

Daimah lil Bubuts al-Imiyah wal Ifta'), sumber: https://archive.org/details/KumpulanFATWA, Diakses 26 juni 2019.

Fitri Nur Hasanah, "Pendidikan Karakter Kajian Pemikiran Imam Al-Ghazali dalam Kitab Ayyuhal Walad", Skripsi--Institut Agama Islam Negeri Salatiga, 2017.

Hartanto, Keluarga Berencana dan Kontrasepsi, Jakarta: Pustaka Sinar Harapan, 2010.

lhttps://asysyariah.com/biografi-as-y-syaikh-abdul-aziz-bin-bazrahimahullah/“diakses pada" 25 Juni 2019

Imam Muslim, Sahib Muslim, Software Jawami’ al-Kalim.

M. Ali Hasan, Masail Fiqhiyah al-Haditsah: pada Masalah-masalah Kontemporer Hukum Islam, Jakarta: PT RajaGrafindo Persada, 1998.

M. Sholihin, Epistemologi Ilmu dalam Pandangan Imam Al-Ghazali, Jakarta: Pustaka Setia, 2001.

Mardhiyah, "Pengaruh Keikutsertaan Keluarga Berencana terhadap Peningkatan Pendidikan Anak di Kelurahan Pulau Kijang", Tesis--Universitas Islam Negeri Suska Riau, 2012.

Muhammad Luthfi Afif, "Keluarga Berencana dalam Tafsir alAzhar”, Skripsi--Universitas Islam Negeri Walisongo, Semarang, 2018.

Musnad Anas bin Malik ra, Hadis nomor 13308, Software Jawami' al-Kalim.

Soerjono Soekanto, Sosiolosi Suatu Pengantar, Jakarta: Cv Rajawali, 1992.

Suhaedah, "Pengaturan Jarak Kehamilan Menurut al-Qur'an", Skripsi-Universitas Islam Negeri Alauddin, Makassar, 2013. 
Rifdatus Sholihah: Hukum Mencegah Kehamilan......

Syekh Muhammad Yusuf Qardhawi, Halal dan Haram dalam Islam, Surabaya: Bina Ilmu, 1993.

Syekh Wahbah Az-Zuhayli, Al-Fiqbul Islami wa Adillatubu, cetakan ke-2, 1985 M/1305, Beirut: Darul Fikr.

Undang-Undang Perkawinan No. 1 Tahun 1974 Tentang Perkawinan. 